\title{
11. QUATERNARY RADIOLARIANS FROM THE EQUATORIAL PACIFIC, DEEP SEA DRILLING PROJECT LEG 85 ${ }^{1}$
}

\author{
Monique Labracherie, Département de Géologie et Océanographie, Université de Bordeaux I²
}

\begin{abstract}
Quaternary radiolarians are common and rather well preserved in the sections recovered from DSDP Holes 571, $572 \mathrm{~A}$, and 573. The assemblages from Hole $575 \mathrm{C}$ are less abundant and contain high concentrations of reworked specimens. Twelve first occurrences, extinction levels, and transitions, some of which are already known in the equatorial Pacific area, are recognized in the interval between the top of the Olduvai and the present (approximately between the Pliocene/Pleistocene boundary and the Holocene). These radiolarian events are compared and correlated with both the paleomagnetic time scale and the carbonate content determined from an undisturbed section with a high sediment accumulation rate.
\end{abstract}

\section{INTRODUCTION}

Numerous biostratigraphic studies have shown the usefulness of radiolarian species for interpretation of the Quaternary. Nigrini's (1971) Quaternary radiolarian zonation of the tropical Pacific presented the main stratigraphic markers. Later, Johnson and Knoll (1975) proposed age estimates for zonal boundaries of this zonation by correlation with paleomagnetic stratigraphy. Recently, Goll (1980) did not apply Nigrini's zonation to the eastern province of the equatorial Pacific, because of the absence of some biostratigraphic indicator taxa. The presence of radiolarians more typical of eastern equatorial assemblages gave him the opportunity to establish a new biozonation with a high resolution. One of the disadvantages of the fourfold Quaternary zonation proposed by Nigrini (1971) is indeed the relatively long timerange of biozones 3 and 4 (the Amphirhopalum ypsilon Interval-Zone and the Anthocyrtidium angulare RangeZone).

Leg 85 coring recovered sediments containing especially diverse and abundant Quaternary radiolarians. Radiolarian assemblages were examined in 4 of 17 holes on Leg 85 . These four holes $(571,572 \mathrm{~A}, 573$, and $575 \mathrm{C})$ are situated in two regions of the equatorial Pacific: Holes 573 and $575 \mathrm{C}$ at approximatively $0^{\circ} \mathrm{N}, 134^{\circ} \mathrm{W}$ and $5^{\circ} \mathrm{N}$, $134^{\circ} \mathrm{W}$, respectively, and Holes $572 \mathrm{~A}$ and 571 at about $1^{\circ} \mathrm{N}, 114^{\circ} \mathrm{W}$ and $4^{\circ} \mathrm{N}, 114^{\circ} \mathrm{W}$, respectively toward the East Pacific Rise (Fig. 1).

All radiolarian datum levels of Johnson and Knoll (1975) and some biohorizons or evolutionary lineages of Goll (1980) are easily recognizable in Leg 85 sediments. They correlate directly with stratigraphies based upon paleomagetism (Weinreich and Theyer, this volume) and/ or carbonate content (Pujos, this volume).

\footnotetext{
${ }^{1}$ Mayer, L., Theyer, F., Thomas, E., et al., Init. Repts. DSDP, 85: Washington (U.S. Govt, Printing Office).

2 Address: Département de Géologie et Océanographie, Laboratoire associé au C.N.R.S. no. 197, Université de Bordeaux I, Avenue des Facultés, 33405 Talence Cedex, France.
}

\section{PROCEDURES}

Cores from Holes 571 and $575 \mathrm{C}$ were sampled at 20 -cm intervals. In cores from Holes 573 and $572 \mathrm{~A}$, only three or four samples per core were analyzed. Sediments were treated with $\mathrm{H}_{2} \mathrm{O}_{2}$ and $\mathrm{HCl}$ and sieved through a $45-\mu \mathrm{m}$ screen. Strewn slides were also prepared, following the procedures outlined by Riedel and Sanfilippo (1977).

In the Quaternary stratigraphic zonation schemes based on the radiolarian fauna, the definition of limits of species range is somewhat ambiguous because of (1) low abundances of the marker taxa, resulting from their usually strong dilution in the biosiliceous (radiolarian) assemblages, (2) fragility of skeletons of some stratigraphic indicator radiolarians, causing poor preservation and (3) the possibility of reworking.

In this investigation of radiolarians from Leg 85 Quaternary sequences, for each sample, about 500 specimens were counted on one slide, along several horizontal traverses, and the main species found in this geographic area were noted. Six categories were used to indicate the relative abundances of selected taxa (see Tables 1 to 4 ). The level for each species event was chosen as the lowermost or uppermost sample-bounding an interval of regular presence-in which the taxon occurs; in the ideal cases, these samples show an increased abundance (above the first-occurrence level) and a decreased abundance (below extinction level) of the taxon, respectively.

\section{QUATERNARY ZONATION}

The main faunal constituents of Leg 85 radiolarian assemblages are typically equatorial and tropical; but species more specifically associated with the Peru coastal upwelling are present (Romine and Moore, 1981). The low-latitude radiolarian zonation of Nigrini (1971) is applied as a starting point to describe the radiolarians at each site (Table 5). The radiolarian zonal sequence used to characterize these Pleistocene assemblages includes events identified in both central and eastern equatorial provinces of the Pacific Ocean. The paleomagnetism record is used as the basis for the chronostratigraphy, and fluctuations in carbonate content are used for the local correlations.

\section{Site 571}

Core 571-1 contains Quaternary assemblages of good to moderate preservation (Table 1). Changes in the preservation of biogenic silica can be correlated with impor- 


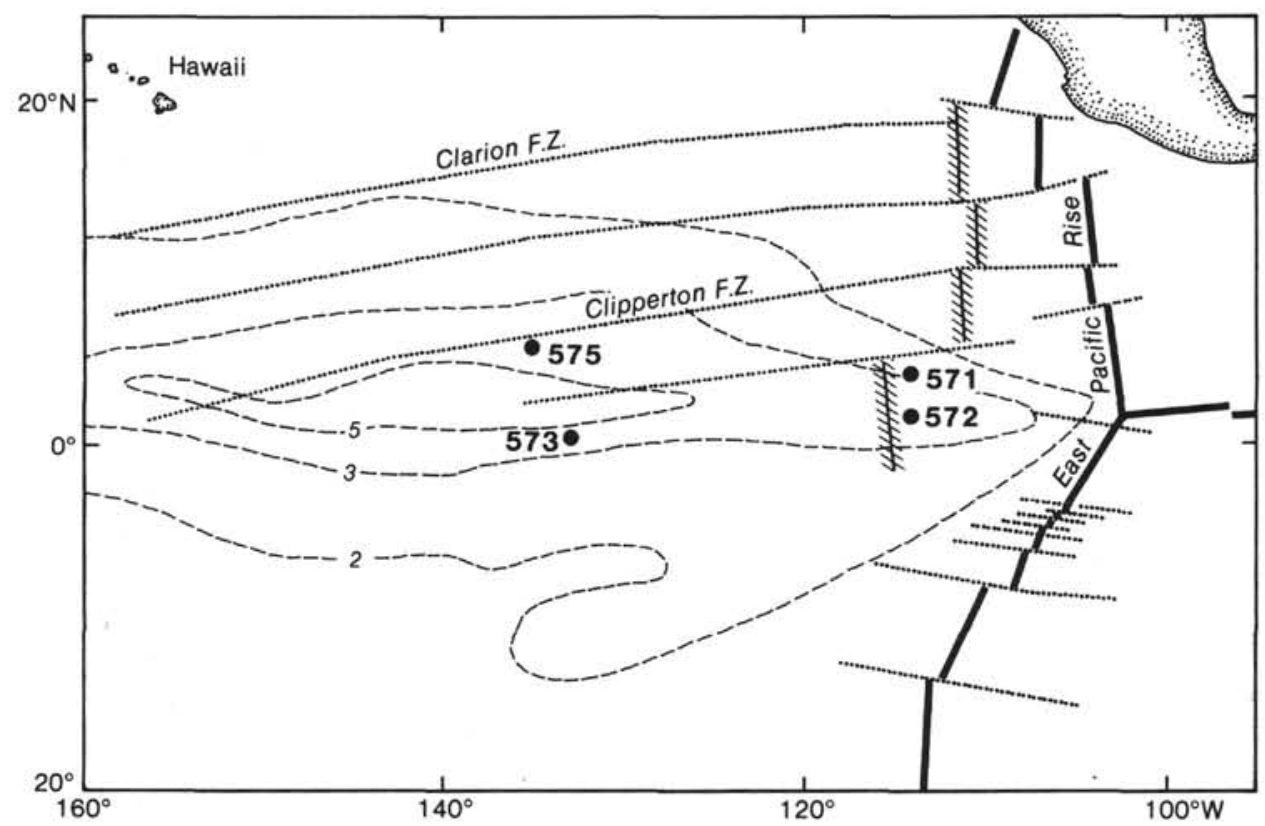

Figure 1. Locations of Sites 571, 572, 573, and 575 (Leg 85) in relation to sediment thickness (broken contours) and fracture zones. Contour intervals are in tenths of seconds of two-way traveltime.

tant fluctuations in the carbonate content. Minima and maxima in the carbonate content at Site 571 are given by Pujos (this volume). Radiolarians from carbonate-rich sediments are abundant, well preserved, and diluted by centric diatoms. Assemblages are generally more poorly preserved within intervals where the carbonate content is minimal. Samples 571-1-2, 41-43 cm, 571-1-3, 18-20 cm, and $571-1-4,118-120 \mathrm{~cm}$ yielded many broken forms, associated sometimes with numerous Ethmodiscus fragments, whereas centric diatoms become rare or absent in the fraction greater than $45 \mu \mathrm{m}$. Radiolarians are diluted by clay aggregates, which may be trapped inside skeletons.

Hole 571 reached only the uppermost levels of the Quaternary. Abundances of some radiolarians are shown in Table 1. Specimens indicative of the uppermost two Quaternary zones of Nigrini's (1971) zonation are common throughout the top meter. These species decrease or disappear below the minima in the carbonate content. The uppermost samples (571-1-5, 21-23 cm through 571$1, \mathrm{CC}, 20 \mathrm{~cm}$ ) containing Axoprunum angelinum ( $=$ Stylatractus universus) can be considered older than 410,000 yrs. (age estimated by Hays and Shackleton [1976] for the extinction level of this species over the whole of its geographic distribution). The date of its last appearance has been differently estimated at 320,000 yrs. ago in the equatorial Pacific (Johnson and Knoll, 1975).

\section{Site $\mathbf{5 7 2}$}

Sediments from the upper $26 \mathrm{~m}$ of Hole 572A (Cores 572A-1 through 572A-3) represent a continuous record throughout the Quaternary of the eastern equatorial Pacific. Sediments contain well-preserved to moderately well preserved radiolarian assemblages diluted with dia- toms. Reworking is minor and occasional (Table 2). The high diversity of assemblages reveals biogeographic correlations with the radiolarian fauna from DSDP sites of the East Pacific Rise and the Galapagos Spreading Center (Goll, 1980); species belonging to the genus Acrosphaera are always more scarce, however.

The four Quaternary zones of Nigrini's (1971) tropical zonation can be recognized, but some events described by Goll (1980), using data from Leg 54 sites, are also represented in the assemblages from Hole 572A. Approximately the uppermost $43 \mathrm{~cm}$ are from the $B u c$ cinosphaera invaginata Zone, and the underlying $5 \mathrm{~m}$ are from the Collosphaera tuberosa Zone. Samples 572A$1-5,117-119 \mathrm{~cm}$ (7.17 $\mathrm{m}$ sub-bottom) and $572 \mathrm{~A}-2-3,118-$ $120 \mathrm{~cm}(13.70 \mathrm{~m})$ contained the uppermost occurrences of Axoprunum angelinum and Amphispyris roggentheni, respectively. This latter species, described by Goll (1980), was originally reported in the eastern Pacific, where it. became extinct about 650,000 yrs. ago. The transition from Androspyris anthropiscus to A. huxleyi can be placed between Samples 572A-2-2, 37-39 cm (last occurrence of $A$. anthropiscus) and 572A-1-6, 76-78 cm (first occurrence of $A$. huxleyi). There is a gap between the two events, which occurs between the uppermost occurrences of $A$. angelinum and $A$. roggentheni. Sporadic occurrences of Androspyris specimens have been mentioned by Goll (1980), and can explain why it is difficult to place exactly the limit of the A. anthropiscus- $A$. huxleyi transition in Hole 572A. Goll (1980) gave it a date of about 500,000 yrs. ago. Samples 572A-2-6, 117-119 cm through $572 \mathrm{~A}-3-2,142-144 \mathrm{~cm}$ have been assigned to the Anthocyrtidium angulare Zone. The uppermost occurrence of Pterocanium prismatium, between Samples $572 \mathrm{~A}-3-5,118-120 \mathrm{~cm}$ and $572 \mathrm{~A}-3-5,141-143 \mathrm{~cm}$, places the Pliocene/Pleistocene boundary near $26 \mathrm{~m}$ sub-bottom. 
Table 1. Ranges and frequency of selected radiolarian species, DSDP Hole 571.

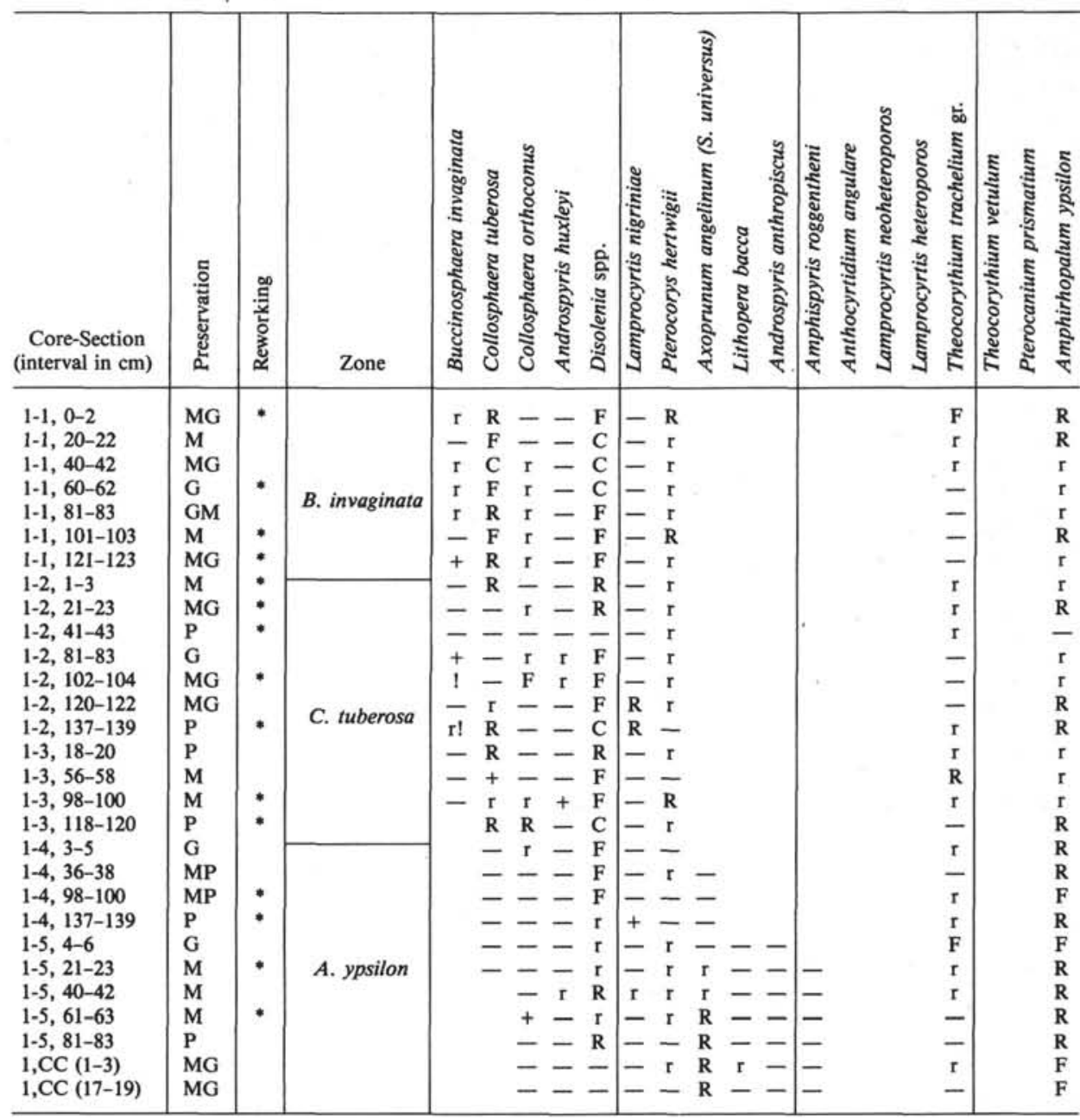

Note: Species abundances: $-=$ species sought but not found; $+=$ present $(<0.15 \%$ of the encountered radiolarians with a constant species numeration, generally about 1 specimen per slide); $r=$ very rare specimens $(0.15-0.99 \%) ; R$ $=$ rare specimens $(1-2.99 \%) ; \mathrm{F}=$ few specimens $(3-9.99 \%) ; \mathrm{C}=$ common $(>10 \%$ or more than about 60 specimens per slide); $!=$ reworking. Preservation of the assemblage: $\mathrm{P}=$ poor; $\mathrm{M}=$ moderate; $\mathrm{G}=$ good. Reworking: $*$ = low.

\section{Site 573}

Hole 573 was drilled farther west in the equatorial Pacific, and is the southernmost hole of Leg 85. The magnetostratigraphy provided by the major polarity-reversal events in this hole (Weinreich and Theyer, this volume) places the base of the Quaternary between Samples $573-4-3,88 \mathrm{~cm}$ and $573-4-3,136 \mathrm{~cm}$, at the top of the Olduvai event (Berggren et al., 1980). A record of fluctuations in calcium carbonate content is also available from this same hole (Pujos, this volume).

On average, radiolarians are moderately well preserved, abundant to common, and somewhat diluted by diatoms, with a very small number of reworked Pliocene and Miocene species. Pliocene radiolarians (especially Spongaster pentas) occur in well-preserved Pleistocene assemblages. Older forms are mixed into more poorly preserved assemblages. Relative abundances of radiolarians, and the zonation, are shown in Table 3. Preservation is very good at the top (Cores 573-1 and 573-2). The Buccinosphaera invaginata and Collosphaera tuberosa zones oc- cupy about the upper 0.70 and $4.5 \mathrm{~m}$, respectively. The first-occurrence level of $C$. tuberosa lies above poorly preserved samples. The Amphirhopalum ypsilon Zone is quite thick (about $14 \mathrm{~m}$ ). Within this broad interval, the last occurrence of Axoprunum angelinum (= Stylatractus universus) is between Samples 573-2-3, 145-147 cm and $573-2-4,36-40 \mathrm{~cm}$. The average relative-abundance curve of this taxon seems to indicate that its upper limit could have been truncated, because the progressive final decline (Hays and Shackleton, 1976) was not observed. Only two samples contain Androspyris anthropiscus, and the last occurrence of Amphispyris roggentheni is between Sample 573-3-2, 35-37 cm and 573-3-2, 85-87 cm. The Anthocyrtidium angulare Range Zone is bounded by both the extinction levels of $A$. angulare and Lamprocyrtis neoheteroporos, at the top, and the first occurrence of $A$. angulare, just above the uppermost occurrence of Pterocanium prismatium at the base. In Hole 573 , this last species is very abundant in its uppermost occurrence, which coincides exactly with the top of the Olduvai. 
Table 2. Ranges and frequency of selected radiolarian species, DSDP Hole 572A.

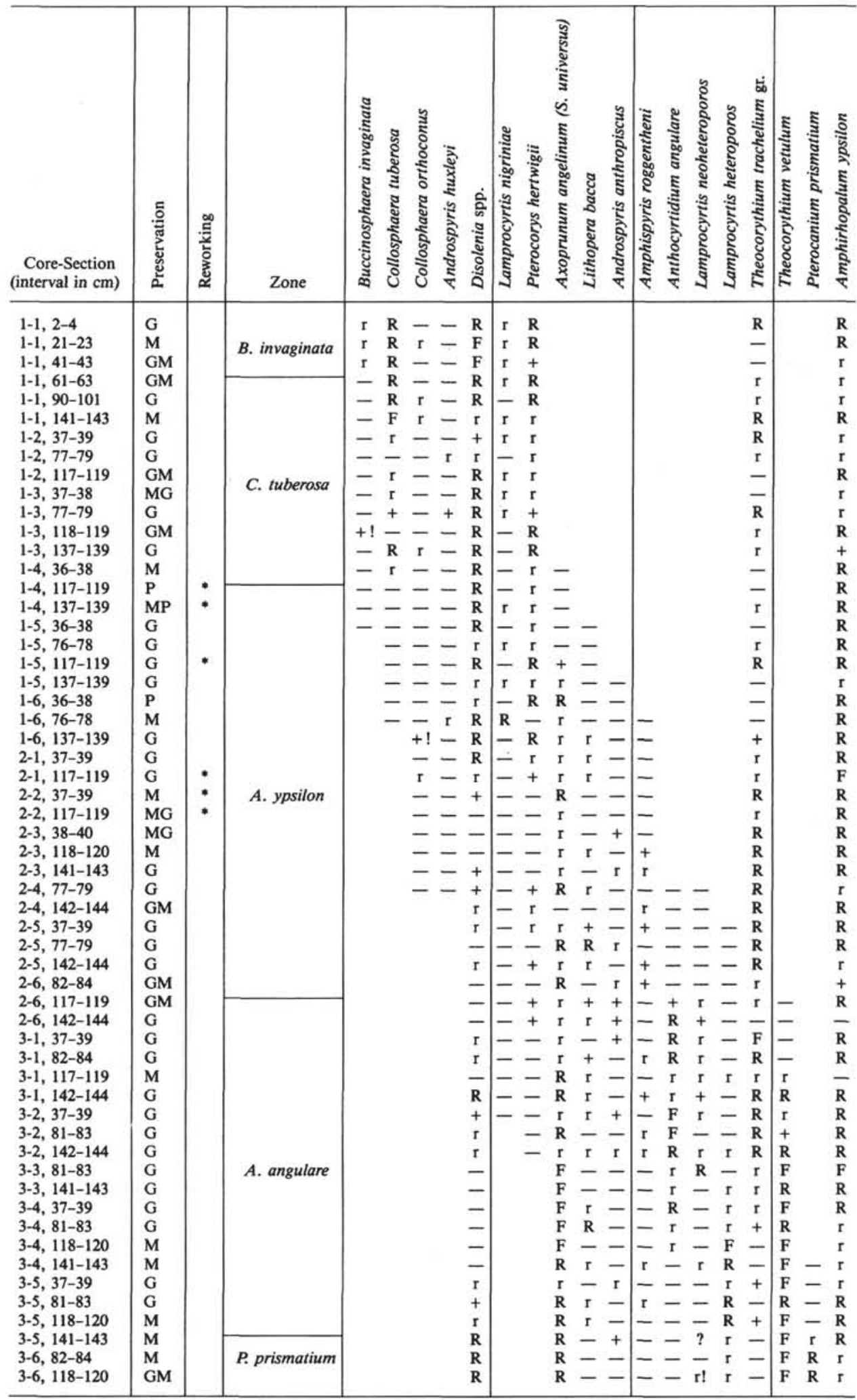

Note: Symbols for species abundances, preservation, and reworking as in Table $1 ; ?=$ doubtful. 
Table 3. Ranges and frequency of selected radiolarian species, DSDP Hole 573.

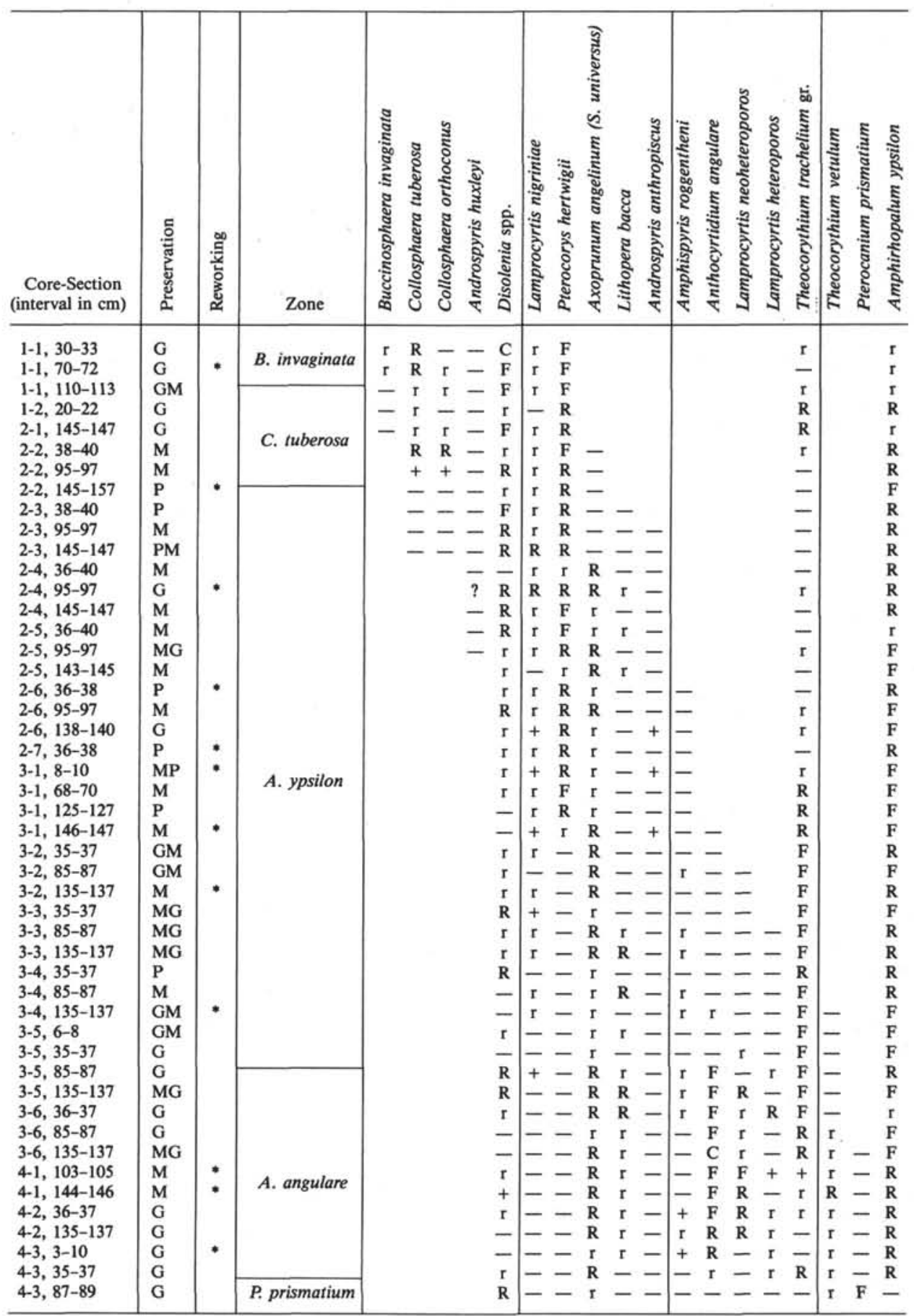

Note: Symbols for species abundances, preservation, and reworking as in Table 2.

\section{Site 575}

Hole $575 \mathrm{C}$, at $6^{\circ} \mathrm{N}$ near the Clipperton Fracture Zone, is the northernmost site of Leg 85. Magnetic stratigraphy was established (Weinreich and Theyer, this volume) and the Pliocene/Pleistocene boundary placed between Samples $575 \mathrm{C}-1-3,106 \mathrm{~cm}$ and $575 \mathrm{C}-1-3,116 \mathrm{~cm}$. Hole $575 \mathrm{C}$ reached the uppermost level of the Pliocene at $4.11 \mathrm{~m}$ sub-bottom. Percentages of calcium carbonate were not determined. Pleistocene sedimentation appears to have been strongly influenced by bottom currents. The rate of sediment accumulation was lower in this hole, even though it was drilled in the high-productivity area, and the sediments contain very high proportions of reworked Tertiary radiolarians throughout the entire section. Reworking is especially important near the Pliocene/Pleistocene and Brunhes/Matuyama boundaries; it dominates the younger assemblages in the upper part of the Brunhes, except those of some uppermost levels. Preservation of Pleistocene radiolarians is regularly poor 
Table 4. Ranges and frequency of selected radiolarian species, DSDP Hole 575C.

\begin{tabular}{|c|c|c|c|c|c|c|c|c|c|c|c|c|c|c|c|c|}
\hline $\begin{array}{c}\text { Core-Section } \\
\text { (interval in } \mathrm{cm} \text { ) }\end{array}$ & 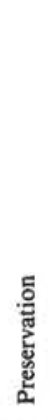 & 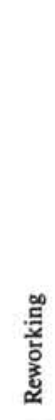 & Zone & 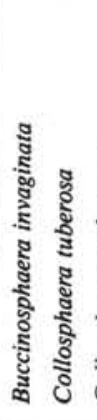 & 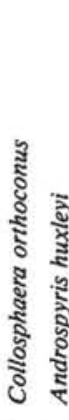 & 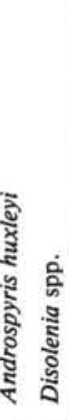 & 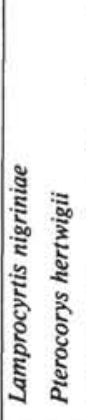 & 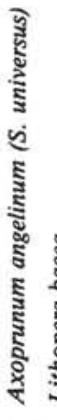 & 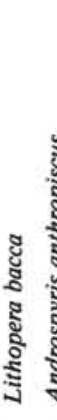 & 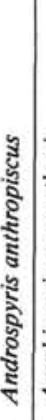 & 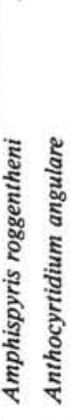 & 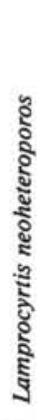 & 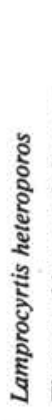 & 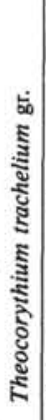 & 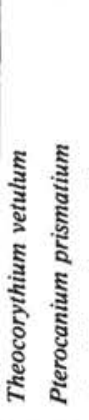 & 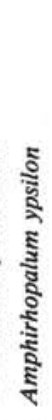 \\
\hline $1-1,5-7$ & M & * & & $\mathrm{r}$ & - & $-F$ & -- & & & & & & & - & & + \\
\hline $1-1,25-27$ & $\mathrm{M}$ & * & B. invaginata & $+R$ & - & $-r$ & -- & & & & & & & - & & - \\
\hline $1-1,45-47$ & M & $*$ & & & $r-$ & $-r$ & -- & -- & - & & & & & - & & $\mathrm{r}$ \\
\hline $1-1,65-67$ & $P$ & $* * *$ & C. tuberosa & -+ & -- & $-r$ & $r-$ & -- & - & & & & & - & & $r$ \\
\hline $1-1,85-87$ & $\mathrm{P}$ & $\because *$ & \multirow{13}{*}{ A. ypsilon } & $?$ & & $\begin{array}{ll}? \mathrm{r} \\
\mathrm{l}\end{array}$ & -- & -- & - & & & & & $\mathrm{r}$ & & - \\
\hline $1-1,105-107$ & P & & & $?$ & R - & -- & +- & -- & - & & & & & r & & $\mathrm{r}$ \\
\hline $1-1,125-127$ & M & $\cdots$ & & - & $r-$ & -- & +- & r & $\mathrm{r}$ & & & & & $\mathbf{R}$ & & $\mathbf{R}$ \\
\hline $1-1,145-147$ & $P$ & $* * *$ & & - & - & -- & -- & $r \quad r$ & $\mathrm{r}$ & & & & & $\mathrm{r}$ & & $\mathbf{F}$ \\
\hline $1-2,15-17$ & MP & $* *$ & & & $\mathrm{r}-$ & -- & -- & r - & - & & & & & $\mathrm{r}$ & & F \\
\hline $1-2,35-37$ & MP & - & & & $r-$ & -- & -- & $\mathrm{r}-$ & - & & & & & - & & F \\
\hline $1-2,55-57$ & M & * & & & - & -- & -- & + & -- & - & - & & & - & & $R$ \\
\hline $1-2,85-87$ & M & • & & & & & & r & & $-1-$ & - & & & $\mathrm{r}$ & & $\mathbf{F}$ \\
\hline $1-2,95-97$ & M & $* * *$ & & & & & & $\mathrm{r}-$ & -- & - & - & & & F & & F \\
\hline $1-2,115-117$ & MG & $* *$ & & & & & & ++ & +- & - & +- & & & $\mathrm{F}$ & & r \\
\hline $1-2,135-137$ & M & * & & & & & & +- & - & - & +- & - & & $\mathrm{r}$ & & I \\
\hline $1-2,145-147$ & MG & ** & & & & & & $-r$ & $\mathrm{r}$ & - & $r-$ & $\mathrm{r}$ & & $\mathbf{R}$ & & r \\
\hline $1-3,5-7$ & $\mathrm{P}$ & $*$ & & & & & & +1 & r & - & $r-$ & r & - & $\mathbf{r}$ & & $\mathrm{r}$ \\
\hline $1-3,25-27$ & $P$ & **.. & \multirow{5}{*}{ A. angulare } & & & & & -- & - & - & $\begin{array}{ll}r & r\end{array}$ & $r$ & - & - & - & \\
\hline $1-3,45-47$ & MG & $\cdots$ & & & & & & r $r$ & $\mathrm{r}$ & - & r $\quad R$ & $\mathbf{R}$ & - & $\mathrm{r}$ & - & $\mathrm{F}$ \\
\hline $1-3,65-67$ & MG & $* *$ & & & & & & $r \quad r$ & $\mathbf{r}$ & - & $-R$ & r & r & $\mathrm{r}$ & -- & $\mathrm{r}$ \\
\hline $1-3,85-87$ & $\mathbf{P}$ & $* *$ & & & & & & r - & - & - & $\begin{array}{ll}r & r\end{array}$ & - & r & $\mathrm{r}$ & r - & + \\
\hline $1-3,105-107$ & $\mathbf{P}$ & $* * *$ & & & & & & r & - & - & -- & + & $\mathrm{r}$ & - & r - & - \\
\hline $1-3,115-117$ & P & $* * *$ & P. prismatium & & & & & r & $\mathrm{r}-$ & -- & $-r$ & - & $\mathrm{r}$ & $\mathrm{r}$ & $-r$ & - \\
\hline
\end{tabular}

Note: Species abundances are estimated. Symbols for abundance, preservation, and reworking as in Table 2. (Additional symbols for reworking: $* *=$ moderate; $* * *=$ high.)

to moderate, and may explain the discontinuous occurrences. All stratigraphic indicator species are scarce, but the different radiolarian zones or events could be observed (Table 4). Buccinosphaera invaginata is confined to a thin surface layer about $25 \mathrm{~cm}$ thick, and Collosphaera tuberosa occurs within the topmost meter. The genus Acrosphaera is exceptionally abundant at the top of the Quaternary sequence. The Anthocyrtidium angulare Zone occupies a short interval, and the first and the last occurrences of $A$. angulare are recorded in poorly preserved samples. The extinction level of Pterocanium prismatium coincides with the upper boundary of the Olduvai event.

\section{CORRELATIONS AND DISCUSSION}

Discussion of the correlations of sequences here proceeds from the base (Pliocene/Pleistocene boundary) to the top (the present). Hole 573 was chosen as the reference Quaternary section for Leg 85 because levels of lowermost and uppermost occurrence can be compared with both the paleomagnetism record (Weinreich and Theyer, this volume) and the calcium carbonate curve (Pujos, this volume). Moreover, Hole 573 yielded an almost undisturbed succession having a high sediment accumulation rate (Figs. 2 and 3 ).

The Pliocene/Pleistocene boundary is placed near the top of the Olduvai polarity event according to Berggren et al. (1980); it is very close to the extinction level of Pterocanium prismatium (about $1.65 \mathrm{Ma}$ ). It seems necessary, however, to discuss the exact characteristics of the upper limit of the Pterocanium prismatium Zone emended by Riedel and Sanfilippo (1977). Goll (1980) mentioned that the last appearance of $P$. prismatium was diachronous in the equatorial Pacific; that is, there was a gap between this event and the first appearance of Lamprocyrtis nigriniae, and consequently there is no radiolarian biohorizon for the Pliocene/Pleistocene boundary.

In Holes 573 and $575 \mathrm{C}$ the upper limit of Pterocanium prismatium coincides with the Pliocene/Pleistocene boundary and the first occurrence of Anthocyrtidium angulare. These events mark also the top of carbonate-dissolution cycle M17, which has been correlated with the top of the Olduvai (Hays et al., 1969 and Gardner, 1982). The last occurrence of Theocorythium vetulum is higher in the section. In Hole 572A P. prismatium becomes extinct at the top of carbonate stage M17, but there is a gap between this extinction level and the first occurrence of $A$. angulare, which lies higher in the sequence.

Farther east (Goll, 1980), A. angulare is even scarcer, and its lower limit is higher in the Pleistocene sequence. This may reflect a true diachronism in the appearance of this species. Interpretation of its morphologic limits becomes more difficult toward the eastern regions of the 
Table 5. Radiolarian zones and events, Holes 571, 572A, 573, and 575C.

\begin{tabular}{|c|c|c|c|c|c|c|}
\hline \multirow[b]{2}{*}{ Age } & \multirow{2}{*}{$\begin{array}{l}\text { Radiolarian zone } \\
\text { (Nigrini, 1971) }\end{array}$} & \multirow[b]{2}{*}{ Radiolarian "event" } & Hole 571 & Hole 572A & Hole 573 & Hole 575C \\
\hline & & & \multicolumn{4}{|c|}{ Core-Section (interval in $\mathrm{cm}$ ) } \\
\hline \multirow{14}{*}{ Quaternary } & B. invaginata & & $1-1,121-123$ & $1-1,41-43$ & $1-1,70-73$ & $1-1,25-27$ \\
\hline & $C$ tuheresa & FO $B$, invaginata & $1-2,1-3$ & $1-1,61-63$ & $1-1,110-113$ & $1-1,35-37$ \\
\hline & C. The to & & $1-3,118-120$ & $1-4,36-38$ & $2-2,95-97$ & $1-1,65-67$ \\
\hline & \multirow{6}{*}{ A. ypsilon } & FO C. tuberosa & $1-4,3-5$ & $1-4,117-119$ & $2-2,145-147$ & $1-1,85-87$ \\
\hline & & $\begin{array}{l}\text { LO A. angelinum } \\
\quad(=S \text {. universus })\end{array}$ & $\begin{array}{l}1-5,21-23 \\
1-5,40-42\end{array}$ & $\begin{array}{l}1-5,76-78 \\
1-5,117-119\end{array}$ & $\begin{array}{l}2-3,145-147 \\
2-4,36-40\end{array}$ & $\begin{array}{l}1-1,105-107 \\
1-1,125-127\end{array}$ \\
\hline & & LO L. bacca & $\begin{array}{l}1-5,81-83 \\
1, \mathrm{CC}(1-3)\end{array}$ & $\begin{array}{l}1-6,76-78 \\
1-6,137-139\end{array}$ & $\begin{array}{l}2-4,36-40 \\
2-4,95-97\end{array}$ & $\begin{array}{l}1-1,105-107 \\
1-1,125-127\end{array}$ \\
\hline & & $\begin{array}{l}\text { A. anthropiscus } \rightarrow \\
\text { A. huxleyi }\end{array}$ & \multirow{9}{*}{$\begin{array}{c}\text { Not } \\
\text { reached }\end{array}$} & $\begin{array}{l}1-6,137-139 \\
2-2,117-119\end{array}$ & $\begin{array}{l}\text { Upper to } \\
2-6,138-140\end{array}$ & $\begin{array}{l}\text { Species sought } \\
\text { but not found }\end{array}$ \\
\hline & & LO $A$. roggentheni & & $\begin{array}{l}2-3,118-120 \\
2-3,141-143\end{array}$ & $\begin{array}{l}3-2,35-37 \\
3-2,85-87\end{array}$ & $\begin{array}{l}1-2,95-97 \\
1-2,115-117\end{array}$ \\
\hline & & & & $2-6,82-84$ & $3-5,35-37$ & $1-3,5-7$ \\
\hline & \multirow{5}{*}{ A. angulare } & LO A. angulare & & $2-6,117-119$ & $3-5,85-87$ & $1-3,25-27$ \\
\hline & & LO L. neoheteroporos & & $\begin{array}{l}2-6,82-84 \\
2-6,117-119\end{array}$ & $\begin{array}{l}3-5,85-87 \\
3-5,135-137\end{array}$ & $\begin{array}{l}1-2,135-137 \\
1-2,145-147\end{array}$ \\
\hline & & $\begin{array}{l}\text { FO acme } T \text {. trachelium } \\
\text { LO } T \text {. vetulum }\end{array}$ & & $\begin{array}{l}3-1,82-84 \\
3-1,117-119\end{array}$ & $\begin{array}{l}3-6,35-37 \\
3-6,85-87\end{array}$ & $\begin{array}{l}1-3,5-7 \\
1-3,85-87\end{array}$ \\
\hline & & $\begin{array}{l}\text { L. heteroporos } \rightarrow \\
\text { L. neoheteroporos }\end{array}$ & & $\begin{array}{l}3-3,81-83 \\
3-3,141-143\end{array}$ & $\begin{array}{l}3-6,135-137 \\
4-1,103-105\end{array}$ & $\begin{array}{l}1-3,65-67 \\
1-3,85-87\end{array}$ \\
\hline & & FO $A$. angulare & & $\begin{array}{l}3-4,118-120 \\
3-4,141-143\end{array}$ & $\begin{array}{l}4-3,35-37 \\
4-3,87-89\end{array}$ & $\begin{array}{l}1-3,85-87 \\
1-3,105-107\end{array}$ \\
\hline Pliocene & P. prismatium & LO $P$ prismatium & & $\begin{array}{l}3-5,118-120 \\
3-5,141-143\end{array}$ & $\begin{array}{l}4-3,35-37 \\
4-3,87-89\end{array}$ & $\begin{array}{l}1-3,105-107 \\
1-3,115-117\end{array}$ \\
\hline
\end{tabular}

Note: $\mathrm{FO}=$ first occurrence; $\mathrm{LO}=$ last occurrence.

Pacific; this explains why Goll has not used the range of $A$, angulare in his stratigraphy of the easternmost Pacific. Unfortunately, the first occurrence of Collosphaera huxleyi, reported by Goll (1980) as marker for the base of the Pleistocene, cannot be useful in this part of the equatorial Pacific, because its occurrences are too sporadic.

Johnson and Knoll (1975) dated the last appearance of $A$. angulare at about 940,000 yrs. ago, whereas Goll (1980) has estimated that this species became extinct about 900,000 yrs. ago. The last occurrence in Hole 573 occurs just below the Jaramillo polarity event and marks carbonate-dissolution cycle M5. The extinction occurs at a level similar to that in the other holes, in higher latitudes (Hole $575 \mathrm{C}$ ) as well as toward the eastern region (Hole 572A); it indicates a date somewhat earlier than the first estimates (approximately $1.05 \mathrm{Ma}$, calculated on the basis of magnetic reversals). This extinction event may be a reliable boundary marker in the equatorial $\mathrm{Pa}$ cific.

Significant changes occur among the radiolarian assemblages within the $A$. angulare Zone of Nigrini (1971), and they could be useful to informally divide it into upper and lower parts. The first occurrence of Theocorythium trachelium could be an eventual marker for the Pliocene/Pleistocene boundary in the equatorial Pacific, but this species occurs in very low numbers in the lowermost Pleistocene. Other workers have reported its extension below the Pliocene/Pleistocene boundary (Johnson, 1974). On the other hand, Nigrini (1971) and Riedel and Westberg (1982) did not find any specimens of
T. trachelium in the P. prismatium Zone. At Leg 85 sites, T. trachelium does show an increased abundance (acme), coincident with the extinction level of Theocorythium vetulum. This occurs within carbonate-dissolution cycle M7 in both Hole 573 and Hole 572A, and may be used to divide the Anthocyrdium angulare Zone into separate parts. The lower part is distinguished by the presence of $T$. vetulum, associated with infrequent T. trachelium and A. angulare. The evolution from Lamprocyrtis heteroporos to $L$. neoheteroporos occurs in this subdivision. The upper part is bounded at the bottom by the lowest occurrence of abundant $T$. trachelium, and is identified by the presence of $L$. neoheteroporos and very common $A$. angulare and $T$. trachelium specimens. The highest occurrence of $L$. neoheteroporos falls very close to the extinction level of $A$. angulare. In Hole 575C the expression of these events is probably masked by the much lower sedimentation rate and the reworking.

Goll has used the extinction level of Amphispyris roggentheni in his zonation of the easternmost equatorial Pacific. The occurrence in Holes 572A, 573, and 575C are the first reported for the central Pacific. In both the east and the central region, this species is always scarce and sporadic; to be certain of its presence, one must study several slides. I consider that in both Hole 573 and Hole $575 \mathrm{C}$ the extinction level of $A$. roggentheni occurs just below the Brunhes/Matuyama boundary, and that in Holes 573 and $572 \mathrm{~A}$ it marks the transition between carbonate-dissolution cycles M1 and B17. This extinction may be a reliable marker in the equatorial $\mathrm{Pa}$ - 


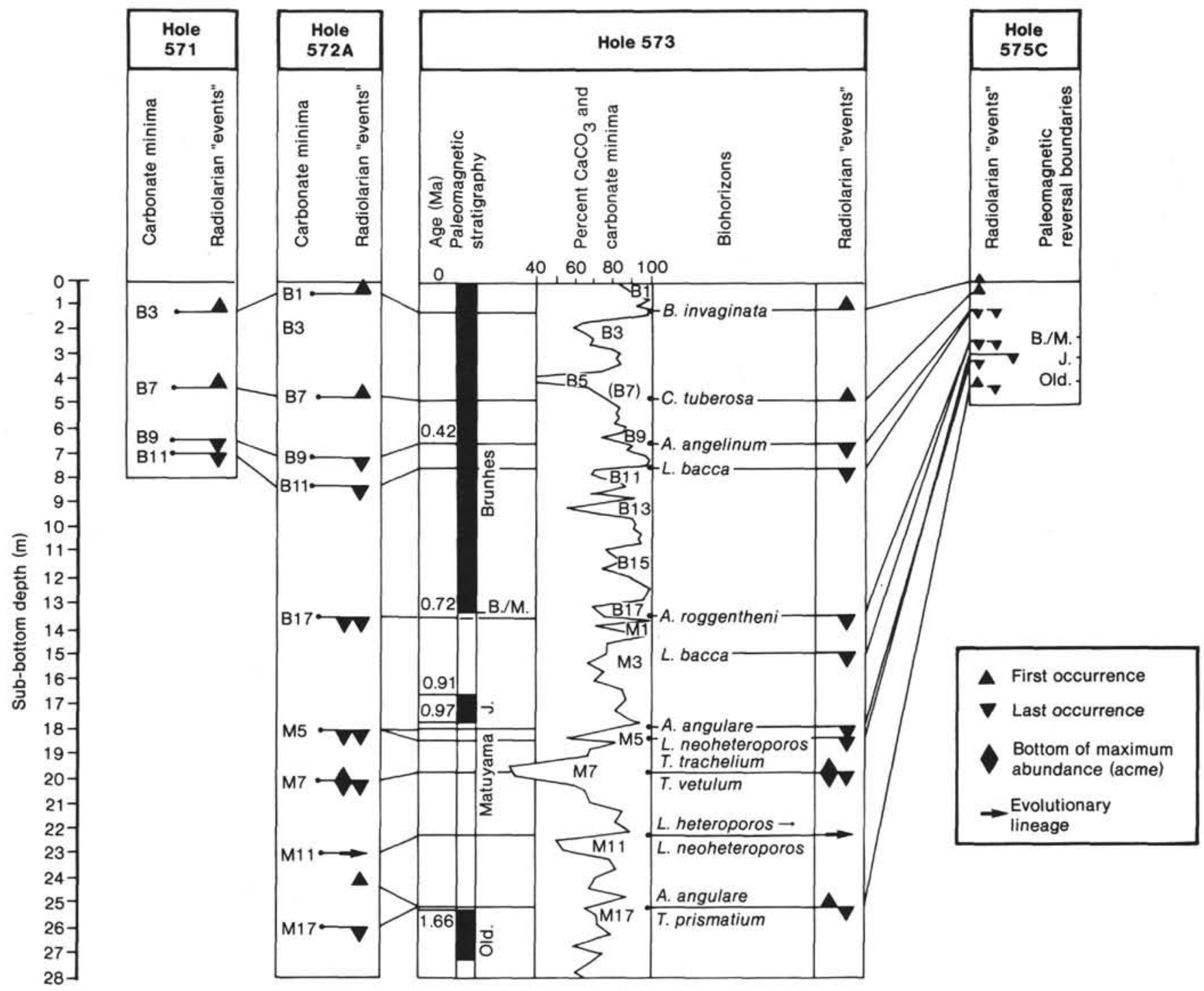

Figure 2. Pleistocene radiolarian biohorizons (events), calcium carbonate fluctuations, and paleomagnetics, Hole 573. Carbonate-minima data from Pujos (this volume). Paleomagnetic stratigraphy from Weinreich and Theyer (this volume). Correlations between four holes of Leg 85 .

cific near the Brunhes/Matuyama boundary, although the scarcity of the species will have to be taken into account when attempting correlations. The timing of this extinction and the possibility of a west-east diachronism will also have to be addressed by further work, because Goll (1980) has estimated this event to be about 650,000 yrs. old in the eastern Pacific. In that region Goll (1980) has reported the highest (last) occurrence of Lithopera bacca just below the highest (last) occurrence of $A$. roggentheni. L. bacca always occurred rather infrequently. A first (i.e., older) highest occurrence level lies at or very close to the extinction level of $A$. roggentheni. However, $L$. bacca recurs in a short interval in the Brunhes. The second (younger) highest occurrence lies just below the highest occurrence of Axoprunum angelinum.

The date of the extinction level of Axoprunum angelinum (= Stylatractus universus Hays) has been estimated in two ways, using (1) a constant accumulation rate between the Brunhes/Matuyama boundary and the present and (2) an astronomical base for the time con- trol. In accord with Hays et al. (1969), the upper limit is synchronous with the top of carbonate maximum peak $\mathrm{B} 10$ in the three holes where the carbonate content has been recorded (Pujos, this volume).

This limit occurs in an interval where the radiolarian assemblages are always well preserved. In correlations between carbonate and oxygen-isotope stratigraphies (Berggren et al., 1980; Gardner, 1982), the transition between carbonate stages B9 and B10 has been correlated with the boundary of isotopic stages 11 to 12 . The age of 421,000 yrs. can be considered as the definitive estimate of the age of this isotopic stage boundary (Morley and Hays, 1981). If one uses this age for the upper limit of Axoprunum angelinum, and if one considers the surface level as representing the Recent sedimentation, it becomes evident that an assumption of a constant accumulation rate between 720,000 yrs. ago and the present is untenable.

The first appearance of Collosphaera tuberosa and Buccinosphaera invaginata correspond to dates presum- 


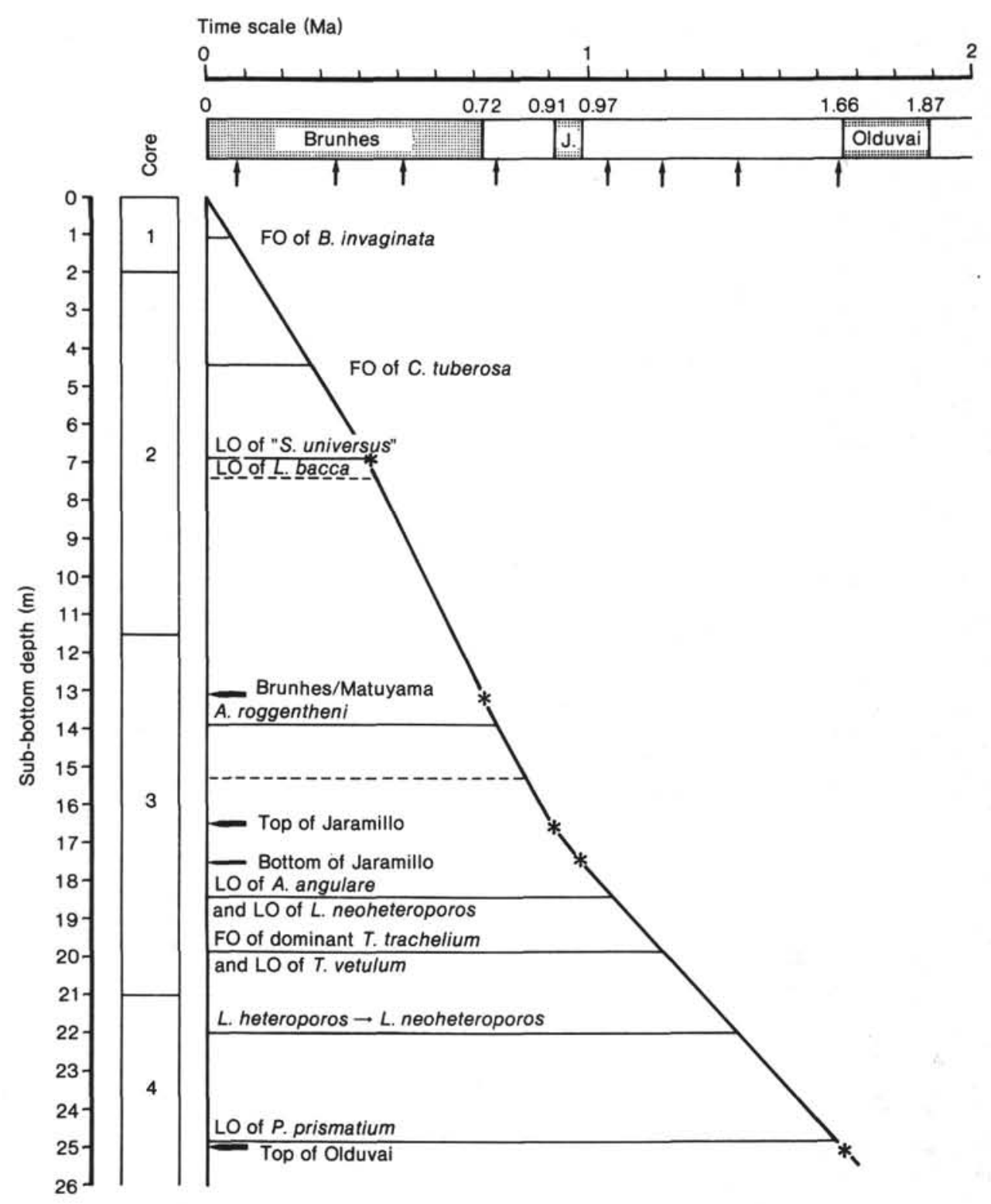

Figure 3. Calibration of Pleistocene radiolarian events, Hole 573. Ages are obtained by extrapolating the sediment accumulation rates between the paleomagnetic boundaries determined by Weinreich and Theyer (this volume) and the estimated date of last occurrence of " $S$. universus," based on time scale of Morley and Hays (1981). FO = first occurrence; LO = last occurrence; asterisks = data points used to construct sedimentation rate curve.

ably later than those reported by Johnson and Knoll (1975). The first occurrence of C. tuberosa often falls above rather poorly preserved samples, and coincides in all cases with the top of carbonate stage B7, which has been correlated (Berggren et al., 1980) with the base of ${ }^{18} \mathrm{O}$ Stage 8 and dated at about 279,000 yrs. (Morley and Hays, 1981). The distribution of Buccinosphaera invaginata coincides with the two upper carbonate stages in Holes 571 and 573. In Hole 572A, calcium carbonate fluctuations seem more complicated.

The first appearance of $B$. invaginata is estimated here at about 65,000 to 72,000 yrs. ago-that is, later than the date determined by Goll (1980). We might have to reconsider the use of these two species for datum levels, because their preservation threshold is very low.

\section{SUMMARY}

Quaternary radiolarians from 4 of the 17 Leg 85 holes were studied intensively. Twelve datum levels, biohorizons, or evolutionary lineages were compared and calibrated using the magnetostratigraphy and carbonate-dissolution cycles of the last 1.7 m.y.

Radiolarians that become extinct in the section representing this interval are Pterocanium prismatium (just above the Olduvai event), Anthocyrtidium angulare and Lamprocyrtis neoheteroporos (just below the Jaramillo event), and Amphispyris roggentheni (just below the Brunhes/Matuyama boundary).

Throughout the Matuyama, the evolutionary lineage from Lamprocyrtis heteroporos to Lamprocyrtis neohet- 
eroporos occurs at the top of carbonate-dissolution cycle M11, and the last occurrence of Theocorythium vetulum is synchronous with the first occurrence of maximum abundance of Theocorythium trachelium, which marks carbonate minimum M7.

Within sediments interpreted as belonging to the Brunhes, Lithopera bacca and Axoprunum angelinum (= Stylatractus universus) bracket carbonate-maximum peak B10. The upper limit of $A$. angelinum is now well known, although it had previously been variously dated between 320,000 and 440,000 yrs.; according to Hays et al. (1969), this extinction occurs near the boundary between carbonate cycles B9 and B10. The use of species belonging to the genus Collosphaera is somewhat unreliable because of their low preservation threshold. But the occurrence of Buccinosphaera invaginata demonstrates that sediments are younger than carbonate minimum B3.

\section{REFERENCES}

Berggren, W. A., Burckle, L. H., Cita, M. B., Cooke, H. B. S., Funnel, B. M., et al., 1980. Towards a Quaternary time scale. Quat. Res., 13:277-302.

Campbell, A. S., and Clark, B. L., 1944. Miocene radiolarian faunas from southern California. Spec. Pap. Geol. Soc. Am., 51:1-76.

Caulet, J. P., 1971. Contribution à l'étude de quelques radiolaires nasselaires des boues de la Méditerranée et du Pacifique. Cah. Micropaleontol., ser. 2, 10:1-10.

1979. Les dépots à Radiolaires d'âge Pliocène supérieur à Pléistocène dans l'océan Indien central: nouvelle zonation biostratigraphique. Mem. Mus. Hist. Nat., 43(C):119-141.

Ehrenberg, C. G., 1872. Mikrogeologischen Studien als Zusammenfassung seiner Beobachtungen des Kleinsten Lebens der MeeresTiefgründe aller Zonen und dessen geologischen Einfluss. Monatsber. Kgl. Preuss. Akad. Wiss. Berlin Jahrg., pp. 265-322.

Gardner, J. V., 1982. High-resolution carbonate and organic-carbon stratigraphies for the late Neogene and Quaternary from the western Caribbean and eastern Pacific. In Prell, W. L., Gardner, J. V., et al., Init. Repts. DSDP, 68: Washington (U.S. Govt. Printing Office), 347-364.

Goll, R. M., 1980. Pliocene-Pleistocene radiolarians from the East Pacific Rise and the Galapagos Spreading Center, Deep Sea Drilling Project Leg 54. In Rosendahl, B. R., Hekinian, R. et al., Init. Repts. DSDP, 54: Washington (U.S. Govt. Printing Office), 425-453.

Haeckel, E., 1887. Report on the Radiolaria collected by H.M.S. Challenger during the years 1873-76. Rep. Sci. Results Voyage H.M.S. Challenger, Zoology, 18:1-1303.

Hays, J. D., 1965. Radiolaria and late Tertiary and Quaternary history of Antarctic seas: biology of the Antarctic Seas. II. Antarct. Res. Ser., 5:125-184.

1970. Stratigraphy and evolutionary trends of radiolaria in North Pacific deep sea sediments. In Hays J. D. (Ed.), Geological Investigations of the North Pacific. Mem. Geol. Soc. Am., 126: $185-218$.

Hays, J. D., Saito, T., Opdyke, N. D., and Burckle, L. H., 1969. Pliocene-Pleistocene sediments of the equatorial Pacific: their paleomagnetic, biostratigraphic, and climatic record. Geol. Soc. Am. Bull., 80:1481-1514.

Hays, J. D., and Shackleton, N. J., 1976. Globally synchronous extinction of the radiolarian Stylatractus universus. Geology, 4: 649-652.

Hedberg, H. D., 1976. International Stratigraphic Guide: A Guide to Stratigraphic Classification, Terminology and Procedure: New York (Wiley-Interscience).

Johnson, D. A., 1974. Radiolaria from the eastern Indian Ocean, DSDP Leg 22. In von der Borch, C. C., Sclater, J. G., et al., Init. Repts. DSDP, 22: Washington (U.S. Govt. Printing Office), 521-575.

Johnson, D. A., and Knoll, A. H., 1975. Absolute ages of Quaternary radiolarian datum levels in the equatorial Pacific. Quat. Res., 5: 99-110.
Kling, S. A., 1973. Radiolaria from the eastern North Pacific, Deep Sea Drilling Project, Leg 18. In Kulm, L. D., von Huene, R., et al., Init. Repts. DSDP, 18: Washington (U.S. Govt. Printing Office), 617-672.

Knoll, A. H., and Johnson, D. A., 1975. Late Pleistocene evolution of the collosphaerid radiolarian Buccinosphaera invaginata Haeckel. Micropaleontology, 21(1):60-68.

Molina-Cruz, A., 1977. Radiolarian assemblages and their relationship to the oceanography of the subtropical southeastern Pacific. Mar. Micropaleontol., 2:315-352.

Morley, J. J., 1980. Analysis of the abundance variations of the subspecies of Cycladophora davisiana. Mar. Micropaleontol., 5: 205-214.

Morley, J. J., and Hays, J. D., 1981. Towards a high resolution, global, deep sea chronology for the last 750,000 years. Earth Planet Sci. Lett., 53:279-295.

Nigrini, C., 1967. Radiolaria in pelagic sediments from the Indian and Atlantic oceans. Scripps Inst. Oceanogr. Bull. 11. 1971. Radiolarian zones in the Quaternary of the equatorial Pacific Ocean. In Funnell, B. M., Riedel, W. R. (Eds.), The Micropalaeontology of the Oceans: Cambridge (Cambridge University Press), pp. 443-461.

Petrushevskaya, M. G., 1968. Radiolarians of orders Spumellaria and Nasselaria of the Antarctic region (from material of the Soviet Antarctic expedition). In Andriyashev, A. P., and Ushakov, P. V. (Eds.), Biological Report of the Soviet Antarctic Expedition (19551958) (Leningrad, 1967 [Isdatel'stp "Nanka"]): Jerusalem (Israel Program for Scientific Translations), pp. 9-156. (Transl. from Russian.)

Riedel, W. R., 1957. Radiolaria: a preliminary stratigraphy. Rep. Swed. Deep-Sea Exped., 6:59-96.

Riedel, W. R., and Sanfilippo, A., 1977. Cenozoic Radiolaria. In Ramsay, A. T. S., Oceanic Micropaleontology: London (Academic Press), pp. 847-912.

1978. Stratigraphy and evolution of tropical Cenozoic radiolarians. Micropaleontology, 24(1):61-96.

Riedel, W. R., and Westberg, M. J., 1982. Neogene radiolarians from the eastern tropical Pacific and Caribbean, Deep Sea Drilling Project, Leg 68. In Prell, W. L., Gardner, J. V., et al., Init. Repts. DSDP, 68: Washington (U.S. Govt. Printing Office), 289-300.

Romine, K., and Moore, T. C., Jr., 1981. Radiolarian assemblage distribution and paleoceanography of the eastern equatorial Pacific Ocean during the last 127,000 years. Palaeogeogr., Paleaeoclimatol., Paleoecol., 35:281-314.

Strelkov, A. A., and Reshetnyak, V. V., 1971. Colonial Spumellarian radiolarians of the world ocean. In Strelkov, A. A. (Ed.), Exploration of the Fauna of the Seas: Moscow (Zool. Inst., Acad. of Sci., U.S.S.R.), 9(17):295-373.

Date of Initial Receipt: 7 November 1983

Date of Acceptance: 22 April 1984

\section{APPENDIX \\ Species List with Bibliography for Taxa Cited ${ }^{3}$ \\ Androspyris anthropiscus Haeckel}

Androspyris anthropiscus Haeckel, 1887, p. 1093, pl. 83, fig. 8; Goll, 1980, p. 436, pl. 4, figs. 2-3.

\section{Androspyris huxleyi (Haeckel)}

Lamprospyris huxleyi Haeckel, 1887, p. 1094, pl. 89, fig. 14. Androspyris huxleyi (Haeckel) Goll, 1980, p. 436. pl. 4, figs. 4-5.

Amphirhopalum ypsilon Haeckel

Amphirhopalum ypsilon Haeckel, 1887, p. 522; Nigrini, 1971, p. 447, pl. 34.1, figs. 7a-c.

\section{Amphispyris roggentheni Goll}

Amphispyris roggentheni Goll, 1980, p. 437, pl. 6, figs. 1, 3, 4, pl. 7, figs. 4-6.

Anthocyrtidium angulare Nigrini

Anthocyrtidium angulare Nigrini, 1971, p. 445, pl. 34.1, figs. 3a-b.

\footnotetext{
${ }^{3}$ See References for full bibliographic data on sources given here.
} 
QUATERNARY RADIOLARIANS FROM THE EQUATORIAL PACIFIC

\section{Axoprunum angelinum (Campbell and Clark)}

Stylosphaera angelina Campbell and Clark, 1944, p. 12, pl. 1, figs. 14-20. Stylatractus universus Hays, 1970, p. 215, pl. 1, figs. 1-2.

Axoprunum angelinum (Campbell and Clark) Kling, 1973, p. 634, pl. 1, figs. 13-16, pl. 6, figs. 14-18.

\section{Buccinosphaera invaginata Haeckel}

Buccinosphaera invaginata Haeckel, 1887, p. 99, pl. 5, fig. 11; Nigrini, 1971, p. 445 , pl. 34.1, fig. 2: Knoll and Johnson, 1975, p. 63, pl. 1, figs. 3-6.

\section{Collosphaera orthoconus (Haeckel)}

Conosphaera orthoconus Haeckel, 1887, p. 221, pl. 12, fig. 2.

Collosphaera sp. A, Knoll and Johnson, 1975, p. 103, pl. 1, fig. 1.

Collosphaera orthoconus (Haeckel) Goll, 1980, p. 436, pl. 1, figs. 10-11.

\section{Collosphaera tuberosa Haeckel}

Collosphaera tuberosa Haeckel, 1887, p. 97; Nigrini, 1971, p. 445, pl. 34.1, fig. 1; Strelkov and Reshetnyak, 1971, pp. 336-337, pl. 4, figs. 24-25; Knoll and Johnson, 1975, p. 63, pl. 2, figs. 1-3.

\section{Cycladophora (?) davisiana Ehrenberg}

Cycladophora davisiana Ehrenberg, 1872, p. 297; Petrushevskaya, 1968, p. 120 , figs. 69-70; Morley, 1980, pl. 1.

\section{Disolenia spp.}

Different species belonging to the genus Disolenia.

\section{Lamprocyrtis heteroporos (Hays)}

Lamprocyclas heteroporos Hays, 1965, p. 179, pl. 3, fig. 1. Lamprocyrtis heteroporos (Hays) Kling, 1973, p. 639, pl. 5, figs. 19-21, pl. 15,
fig. 6 .

\section{Lamprocyrtis neoheteroporos Kling}

Lamprocyrtis neoheteroporos Kling, 1973, p. 639, pl. 5, figs. 17-18, pl. 15, figs. 4-5.

\section{Lamprocyrtis nigriniae (Caulet)}

Conarachnium nigriniae Caulet, 1971, p. 3, pl. 3, figs. 1-4, pl. 4, figs. 1-4 Lamprocyrtis haysi Kling, 1973, p. 639, pl. 5, figs. 15-16, pl. 15, figs. 1-3.

Lamprocyrtis nigriniae (Caulet) Kling, 1973, p. 217, pl. 1, fig. 17.

\section{Lithopera bacca Ehrenberg}

Lithopera bacca Ehrenberg, 1872, p. 314; Riedel and Sanfilippo, 1978, p. 70, pl. 6, fig. 9.

\section{Pterocanium prismatium Riedel}

Pterocanium prismatium Riedel, 1957, p. 87, pl. 3, figs. 4-5; Riedel and Sanfilippo, 1978, p. 72, pl. 9, fig. 1.

\section{Pterocorys hertwigii (Haeckel)}

Eucyrtidium hertwigii (Haeckel), 1887, p. 1491, pl. 80, fig. 12.

Pterocorys hertwigii (Haeckel) Caulet, 1979, pl. 3, fig. 4.

\section{Theocorythium trachelium (Ehrenberg)}

Eucyrtidium trachelius Ehrenberg, 1872, p. 312.

Theocorythium trachelium (Ehrenberg) Nigrini, 1967, p. 77, pl. 8, figs. 1-2, pl. 9, figs, 1-2, Riedel and Sanfilippo, 1978, p. 76, pl. 9, fig. 17.

\section{Theocorythium vetulum Nigrini}

Theocorythium vetulum Nigrini, 1971 , p. 447 , pl. 34.1 , figs. $6 a-b$. 